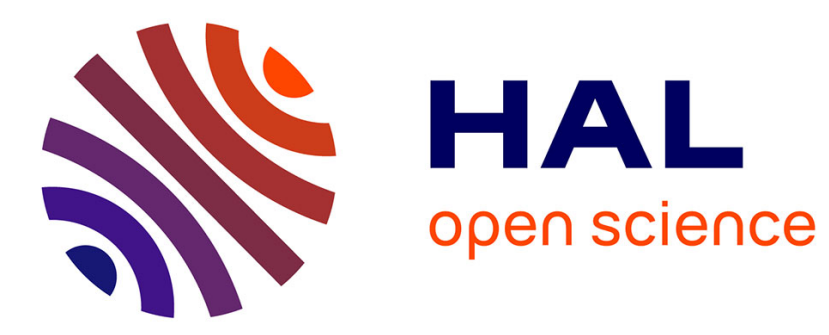

\title{
Serologic survey for toxoplasmosis in domestic poultry from the Czech Republic
}

\author{
Eva Bártová, Kamil Sedlák, Ivan Literák
}

\section{To cite this version:}

Eva Bártová, Kamil Sedlák, Ivan Literák. Serologic survey for toxoplasmosis in domestic poultry from the Czech Republic. Avian Pathology, 2009, 38 (04), pp.317-320. 10.1080/03079450903055405 . hal-00540157

\section{HAL Id: hal-00540157 \\ https://hal.science/hal-00540157}

Submitted on 26 Nov 2010

HAL is a multi-disciplinary open access archive for the deposit and dissemination of scientific research documents, whether they are published or not. The documents may come from teaching and research institutions in France or abroad, or from public or private research centers.
L'archive ouverte pluridisciplinaire HAL, est destinée au dépôt et à la diffusion de documents scientifiques de niveau recherche, publiés ou non, émanant des établissements d'enseignement et de recherche français ou étrangers, des laboratoires publics ou privés. 


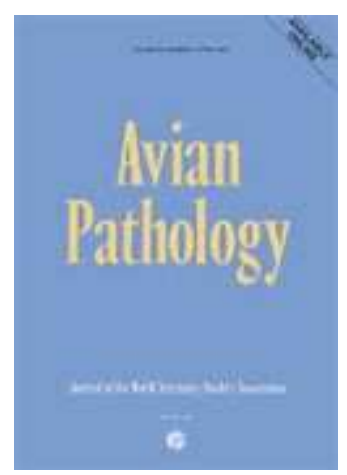

\section{Serologic survey for toxoplasmosis in domestic poultry from the Czech Republic}

\begin{tabular}{|c|c|}
\hline Journal: & Avian Pathology \\
\hline Manuscript ID: & CAVP-2009-0001.R1 \\
\hline Manuscript Type: & Original Research Paper \\
\hline $\begin{array}{r}\text { Date Submitted by the } \\
\text { Author: }\end{array}$ & 24-Feb-2009 \\
\hline Complete List of Authors: & $\begin{array}{l}\text { Bártová, Eva; University of Veterinary and Pharmaceutical Sciences, } \\
\text { Department of Biology and Wildlife Diseases } \\
\text { Sedlák, Kamil; State Veterinary Institute Prague, Department of } \\
\text { Virology and Serology } \\
\text { Literák, Ivan; University of Veterinary and Pharmaceutical Sciences, } \\
\text { Department of Biology and Wildlife Diseases }\end{array}$ \\
\hline Keywords: & toxoplasma gondii, IFAT, water fowls, gallinaceous birds \\
\hline
\end{tabular}

\section{SCHOLARONE Manuscripts}


Serologic survey for toxoplasmosis in domestic birds from the Czech Republic

\section{Eva Bártová ${ }^{1 *}$, Kamil Sedlák $^{2}$ \& Ivan Literák ${ }^{1}$}

${ }^{1}$ University of Veterinary and Pharmaceutical Sciences, Faculty of Veterinary Hygiene and Ecology, Department of Biology and Wildlife Diseases, Palackého 1-3, 61242 Brno, Czech Republic,

${ }^{2}$ State Veterinary Institute Prague, Department of Virology and Serology, Sídlištní, 24, 165 03 Prague 6, Czech Republic

Short title: Domestic birds and T. gondii antibodies

"To whom correspondence should be addressed.

E-mail: bartovae@ vfu.cz Tel: +420 541562633. Fax: +420-5-41562631

-

Received: 2 January 2009 


\section{Summary}

$\mid$

This study was carried out on domestic fowls in the Czech Republic in the years 2003 and

2004. A total of 1108 samples obtained from 538 water birds (geese and ducks) and 570 gallinaceous birds (chickens and turkeys) were tested for specific antibodies against $T$. gondii using the Indirect fluorescence antibody test (IFAT). In geese, $43 \%$ prevalence (77 positive out of 178 examined) was found with titres of 40, 320 and 2,560 in 40, 29 and 8 geese, respectively. In ducks, $14 \%$ prevalence (52 out of 360) was found with titres of 40 and 320 in 46 and 6 ducks, respectively. In gallinaceous birds, only one of 293 broiler chickens was positive with a titre of 40; sera of 217 hens and 60 turkeys were negative. We found extremely higher antibody prevalence in geese and ducks compared to gallinaceous birds. In Europe, it is the first seroprevalence study in domestic birds by IFAT. 


\section{Introduction}

The parasite Toxoplasma gondii causes infections that are widely prevalent in human and warm-blooded animals worldwide (Dubey and Beattie, 1988). Humans can be infected mainly by ingesting $T$. gondii tissue cysts from undercooked meat or $T$. gondii oocysts from the environment contaminated with cat feces. Domestic birds are a good indicator of environmental contamination with parasite oocysts because of their feeding behaviours. Moreover, birds can serve as a potential source of infection for humans. In chickens, T. gondii were found in skeletal muscles, heart, brain, ovary, oviduct, kidney, spleen, liver, lung, pancreas, gizzard, proventriculus, intestine, and retina and even in eggs (Jacobs and Melton, 1966; Kaneto et al., 1997). Tissue cysts of T. gondii were found in breast and leg muscles, heart, brain, liver and stomach of experimentally infected domestic ducks (Bártová et al., 2004).

For testing of $T$. gondii antibodies in domestic birds, different methods were used in Formatted: Indent: First line: 35.4 pt several countries. Indirect fluorescence antibody test (IFAT) was used to test chickens from India (Sreekumar et al., 2001) and Costa Rica (Abrahams-Sandi and Vargas-Brenes, 2005). Modified agglutination test (MAT) was used to test chickens from several countries, e.g. India (Sreekumar et al., 2003), Israel (Dubey et al. 2004b), Mexico (Dubey et al. 2004a) and Chile (Dubey et al., 2006) and to test chickens and ducks from Egypt (Dubey et al., 2003).

In the Czech Republic, the last serologic study in domestic birds was made by the SabinFeldman reaction during the years 1981-1990 (Literák and Hejlíček, 1993). This work is aiming to estimate recent seroprevalence in domestic birds by the IFAT. This method was used in the present prevalence study in several groups of domestic and wildlife animals in the Czech Republic, in order to compare results obtained with the same method.

Deleted: ed Deleted: at Deleted: ing Deleted: ies Deleted: so the obtained results can be Deleted: compared because Deleted: of

Deleted: used 
Materials and Methods

Blood samples. During the years 2003 and 2004, blood samples of 1108 domestic birds from the Czech Republic were examined for the presence of $T$. gondii antibodies. The birds were slaughtered at 14 slaughterhouses and blood was taken by veterinary inspectors during the time of avian influenza surveillance. Birds came from 57 different large-scale farms and one slaughter house of 13 districts (Figure 1) to obtain representative sampling from the whole Czech Republic, taking into account the size and the importance of farms. The blood samples were sent to the State Veterinary Institute in Prague. The blood was centrifuged and sera were stored at $-18{ }^{\circ} \mathrm{C}$ until assayed. Sera of 178 geese, 360 ducks and 570 gallinaceous birds (293 broilers, 217 hens and 60 turkeys) were tested by the IFAT.

Indirect fluorescence antibody test. Antibodies to $T$. gondii were detected in the sera by the IFAT using a commercially available antigen Sevatest Toxoplasma Antigen IFR (Sevac, Prague, the Czech Republic), anti-chicken IgG conjugate (Sigma Aldrich) and anti-duck IgG conjugate (KPL, USA). The sera were diluted in a two-fold series starting at 1:40 as a basic dilution; a titre $\geq 40$ was considered positive. The other dilutions used were 1:320 and 1:2560. Sera of naturally infected domestic geese, Coscoroba swan (Coscoroba coscoroba) and Paradise shelduck (Tadorna variegata) and sera from experimentally infected chickens, turkeys and ducks, positive in both the Latex agglutination test (LAT) and the IFAT, served as the positive control (Table 1). Sera negative in both the LAT and the IFAT served as the negative controls.

\section{Results}

Deleted: Indirect fluorescence antibody test II

Deleted: The list of controls is presented in the Table 1. 
In water birds (geese and ducks) a prevalence of $24 \%$ (129 positive of 538) was found. Deleted:

Antibodies to T. gondii were detected in $43 \%$ (77/178) of geese with titres 40, 320 and 2560 in 40, 29 and eight geese, respectively. Geese came from four different farms with seroprevalences ranging from $19 \%$ to $64 \%$. In ducks, $14 \%(52 / 360)$ prevalence was found with titres of 40 and 320 in 46 and 6 ducks, respectively. Ducks came from nine different farms with seroprevalences ranging from $3 \%$ to $29 \%$ (Table 2). In gallinaceous birds, only one of 293 broiler chickens originating from 29 farms was positive with a basic titre of 40; sera of 217 hens coming from 11 farms and 60 turkeys located on 6 farms, were negative (Table 3). Data did not allow statistical evaluation because of the differences between districts (different number of bird sampled, different number and size of farms examined).

\section{Discussion}

The seroprevalence of $T$. gondii in domestic birds varies within countries due to the methods used for testing the number of examined animals, type and hygiene of animal breeding, etc. In our study, the gallinaceous birds came from large-scale farms with restriction of cat access. This can explain the very low seroprevalence found in this group of birds compared to data obtained in other countries. Antibodies against T. gondii were detected by the MAT in $40 \%$ of chickens from Egypt (Dubey et al., 2003) and in $47 \%$ of free-range chickens from Israel (Dubey et al., 2004b). In Costa Rica (Abrahams-Sandi and Vargas-Brenes, 2005) and India (Sreekumar et al., 2001), a prevalence of $41 \%$ and $22 \%$ were found applying IFAT for chicken sera, There are no data available from the European countries, so this is the first Deleted: prevalence Deleted: by the Deleted: in Deleted: chickens, respectively seroprevalence study in domestic birds by the IFAT in Europe. In contrast to $40 \%$ prevalence 
in chickens and $16 \%$ in ducks from Egypt (Dubey et al., 2003), we found higher prevalence in ducks compared to chickens.

Our results are similar to those obtained in the Czech Republic in the past, even ${ }^{+}$ Formatted: Indent: First line: 35.4 pt though a different method was used. Literák and Hejlíček (1993) made a long-term serological study (1981-1990) in domestic birds coming from South Bohemian district by the SFR. They found a higher prevalence in geese (16\%) compared to ducks $(2 \%)$. In chickens a prvevalence of $5 \%$ was noticed in birds from a small backyard, whereas only one positive chicken was obtained from large-scale commercial farms.

The higher prevalence of antibodies in water birds (geese and ducks) is a good indicator of environmental contamination with oocysts in the sampled areas. Different prevalence was found in geese and ducks. For example, prevalence in geese was 55\% (22/40) and $0 \%(0 / 39)$ in ducks coming from the same farm (D) from the OL district. Different prevalence in geese and ducks can be explained by differences in age of the tested animals, the type of breeding and their feeding habits. In the case of ducks, broilers (young birds) produced in large halls were slaughtered and tested. Since geese are not frequently slaughtered, the blood for the surveillance was obtained from breeding stock, These geese were adult with free access to natural water sources (ponds, lakes) and thus with a greater chance to be infected.

Based on the obtained data ducks and geese can represent a higher risk of infection for Deleted: D consumers, because of a higher prevalence found in this group of birds.

Deleted: from our country

\section{Acknowledgements}

This study was funded by the grant no. MSM6215712402 from the Ministry of Education, Youth and Sports of 
the Czech Republic. We would like to thank MVDr. J. Machová and J. Horníčková from the Czech National Reference Laboratory for Avian Influenza and Newcastle Disease for providing animal samples and to thank Mgr. Zuzana Satková and Bc. Martina Šíblová for their help with examination of samples.

\section{References}

Abrahams-Sandi, E., and Vargas-Brenes, O. (2005). Serological prevalence of Toxoplasma Formatted: Indent: Left, Hanging: $28.35 \mathrm{pt}$ gondii in free-range chickens from Costa Rica. Tropical animal health and production, $37,369-372$

Formatted: Font: Italic

Bártová, E., Dvořáková, H., Bárta, J., Sedlák, K., Literák, I. (2004). Susceptibility of the domestic duck (Anas platyrhynchos) to experimental infection with Toxoplasma gondii oocysts. Avian Pathology, 33, 153-157.

Dubey, J.P. and Beattie, C.P. (1988). Toxoplasmosis of animals and man. CRC Press, Boca Raton, FL, 220 pp.

Dubey, J.P., Graham, D.H., Dahl, E., Hilali, M., El-Ghaysh A., Sreekumar, C., Kwok, O.C.H., Shen, S.K., Lehmann, T. (2003). Isolation and molecular characterization of Toxoplasma gondii from chickens and ducks from Egypt. Veterinary Parasitology, 114,

Formatted: Font: Italic 89-95.

Dubey, J.P., Morales, E.S., Lehmann, T. (2004a). Isolation and genotyping of Toxoplasma gondii from free-ranging chickens from Mexico. Journal of Parasitology, 90, 411-413.

Dubey, J.P., Patitucci, A.N., Su, C., Sundar, N., Kwok, O.C.H., Shen, S.K. (2006). Characterization of Toxoplasma gondii isolates in free-range chickens from Chile, South America. Veterinary Parasitology, 140, 76-82.

Formatted: Font: Italic Dubey, J.P., Salant, H., Sreekumar, C., Dahl, E, Vianna, M.C.B., Shen, S.K., Kwok, O.C.H., Spira, D., Hamburger, J., Lehmann, T. V. (2004b). High prevalence of Toxoplasma 
gondii in a commercial flock of chickens in Israel, and public health implications of free-range farming. Veterinary Parasitology, 121, 317-322.

Jacobs, L., and Melton, M.L. (1966). Toxoplasmosis in chickens. Journal of Parasitology, 52 ,

Formatted: Font: Italic

Formatted: Font: Italic $1158-1162$

Kaneto, C.N., Costa, A.J., Paulillo, A.C., Moraes, F.R., Murakami, T.O., Meireles, M.V. (1997). Experimental toxoplasmosis in broiler chicks. Veterinary Parasitology, 69, 203-

Formatted: Font: Italic 210.

Literák, I. and Hejlíček K. (1993). Incidence of Toxoplasma gondii in populations of domestic birds in the Czech Republic. Avian Pathology, 22, 275-281.

Formatted: Font: Italic

Sedlák, K., Literák, I., Vitula, F., Benak, J. (2000). High susceptibility of partridges (Perdix perdix) to toxoplasmosis compared with other gallinaceous birds. Avian Pathology, 29, $563-569$

Sreekumar, C., Graham, D.H., Dahl, E., Lehmann, T., Raman, M., Bhalerao, D.P., Vianna, M.C.B., Dubey, J.P. (2003). Genotyping of Toxoplasma gondii isolates from chickens from India. Veterinary Parasitology, 118, 187-194.

Sreekumar, C., Rao, J.R., Mishra, A.K., Ray, D., Singh, R.K., Joshi, P. (2001). First isolation of Toxoplasma gondii from chickens in India. Journal of Veterinary Parasitology, 15 , 103-106. 
Table 1. Characteristic of positive and negative controls included in IFAT.

\begin{tabular}{|c|c|c|c|c|}
\hline Controls & Characteristic of controls & $\mathbf{n}$ & $\begin{array}{c}\text { LAT } \\
\text { results }\end{array}$ & $\begin{array}{l}\text { IFAT } \\
\text { results }\end{array}$ \\
\hline \multirow{2}{*}{$\begin{array}{l}\text { Chicken } \\
\text { (negative) }\end{array}$} & Chicken serum, SPF breed, 2 weeks old & 2 & - & - \\
\hline & $\begin{array}{l}\text { Chicken serum before } T \text {. gondii_experimental } \\
\text { infection (Sedlak et al 2000) }\end{array}$ & 5 & - & - \\
\hline $\begin{array}{l}\text { Chicken } \\
\text { (positive) }\end{array}$ & $\begin{array}{l}\text { Chicken serum } 28 \text { d.p.i. with } T . \text { gondii } \\
\text { oocystes (Sedlak et al., 2000) }\end{array}$ & 5 & + & + \\
\hline $\begin{array}{c}\text { Turkey } \\
\text { ( negative) }\end{array}$ & $\begin{array}{l}\text { Turkey serum before } T \text {. gondii experimental } \\
\text { infection (Sedlak et al., 2000) }\end{array}$ & 4 & - & - \\
\hline $\begin{array}{l}\text { Turkey } \\
\text { (positive) }\end{array}$ & $\begin{array}{l}\text { Turkey serum } 21 \text { d.p.i. with } T \text {. gondii } \\
\text { oocystes (Sedlak et al., 2000) }\end{array}$ & 4 & + & + \\
\hline $\begin{array}{c}\text { Duck } \\
\text { (negative) }\end{array}$ & $\begin{array}{l}\text { Duck serum before } T \text {. gondiiexperimental } \\
\text { infection (Bartova et al., 2004) }\end{array}$ & 4 & - & - \\
\hline $\begin{array}{c}\text { Duck } \\
\text { (positive) }\end{array}$ & $\begin{array}{l}\text { Duck serum } 28 \text { d.p.i. with } T \text {. gondii oocystes } \\
\text { (Bartova et al., 2004) }\end{array}$ & 4 & + & + \\
\hline $\begin{array}{c}\text { Geese } \\
\text { (negative) }\end{array}$ & Geese serum & 4 & - & - \\
\hline $\begin{array}{c}\text { Geese } \\
\text { (positive) }\end{array}$ & $\begin{array}{l}\text { Sera of naturally infected domestic geese, } \\
\text { Coscoroba swan (Coscoroba coscoroba) } \\
\text { and Paradise shelduck (Tadorna variegata) }\end{array}$ & $4,1,1$ & + & + \\
\hline
\end{tabular}

Formatted Table


Table 2. Results of T. gondii seroprevalence study in ducks and geese

\begin{tabular}{|c|c|c|c|c|c|c|c|}
\hline \multirow{2}{*}{ Species } & \multirow{2}{*}{ District } & \multirow{2}{*}{ Farm } & \multirow{2}{*}{$\begin{array}{c}\text { No. of } \\
\text { serum } \\
\text { samples }\end{array}$} & \multirow{2}{*}{$\begin{array}{l}\text { No. of positive } \\
\text { samples (\%) }\end{array}$} & \multicolumn{3}{|c|}{ Titres } \\
\hline & & & & & 40 & 320 & 2560 \\
\hline \multirow[t]{4}{*}{ Goose } & South Bohemian & $\mathrm{A}$ & 73 & $14(19 \%)$ & 14 & 2 & - \\
\hline & & B & 39 & $25(64 \%)$ & 25 & 23 & 5 \\
\hline & & $\mathrm{C}$ & 26 & $16(62 \%)$ & 16 & 2 & 1 \\
\hline & Olomouc & $\mathrm{D}$ & 40 & $22(55 \%)$ & 22 & 10 & 2 \\
\hline Total & & & 178 & $77(43 \%)$ & 77 & 37 & 8 \\
\hline \multirow[t]{9}{*}{ Duck } & South Bohemian & $\mathrm{E}$ & 40 & $3(8 \%)$ & 3 & - & - \\
\hline & & $\mathrm{F}$ & 39 & $8(21 \%)$ & 8 & - & - \\
\hline & & G & 40 & $1(3 \%)$ & 1 & - & - \\
\hline & & $\mathrm{H}$ & 40 & 0 & 0 & - & - \\
\hline & & I & 33 & $5(15 \%)$ & 5 & 2 & - \\
\hline & & $\mathrm{J}^{*}$ & 39 & $8(21 \%)$ & 8 & - & - \\
\hline & Hradec Králové & $\mathrm{K}$ & 48 & $15(31 \%)$ & 15 & 2 & - \\
\hline & Pardubice & $\mathrm{L}$ & 42 & $12(29 \%)$ & 12 & 2 & - \\
\hline & Olomouc & $\mathrm{D}$ & 39 & 0 & 0 & - & - \\
\hline Total & & & 360 & $52(14 \%)$ & 52 & 6 & - \\
\hline
\end{tabular}


Table 3. Results of T. gondii seroprevalence study in gallinaceous birds

\begin{tabular}{|c|c|c|c|c|}
\hline Species & District & $\begin{array}{l}\text { No. of } \\
\text { farms }\end{array}$ & $\begin{array}{l}\text { No. of serum } \\
\text { samples }\end{array}$ & $\begin{array}{c}\text { No. of positive } \\
\text { samples (\%) }\end{array}$ \\
\hline \multirow[t]{10}{*}{ Broiler } & South Bohemian & 3 & 30 & - \\
\hline & Plzeň & 2 & 20 & - \\
\hline & Ústí nad Labem & 3 & 30 & $1^{*}$ \\
\hline & Hradec Králové & 3 & 30 & - \\
\hline & Central Bohemian & 5 & 50 & - \\
\hline & Pardubice & 2 & 21 & - \\
\hline & Vysočina & 2 & 21 & - \\
\hline & South Moravian & 7 & 71 & - \\
\hline & Moravian-Silesian & 1 & 10 & - \\
\hline & Zlín & 1 & 10 & - \\
\hline Total & & 29 & 263 & $1(0.4 \%)$ \\
\hline \multirow[t]{6}{*}{ Hen } & South Bohemian & 1 & 11 & - \\
\hline & Ústí nad Labem & 1 & 30 & - \\
\hline & Hradec Králové & 1 & 50 & - \\
\hline & Central Bohemian & 2 & 50 & - \\
\hline & Pardubice & 4 & 56 & - \\
\hline & South Moravian & 2 & 20 & - \\
\hline Total & & 11 & 217 & - \\
\hline \multirow[t]{5}{*}{ Turkey } & Plzeň & 2 & 20 & - \\
\hline & Karlovy Vary & 1 & 10 & - \\
\hline & Liberec & 1 & 10 & - \\
\hline & Vysočina & 1 & 10 & - \\
\hline & Moravian-Silesian & 1 & 10 & - \\
\hline Total & & 6 & 60 & - \\
\hline
\end{tabular}


Figure 1. Map of the Czech Republic showing the sampled areas.

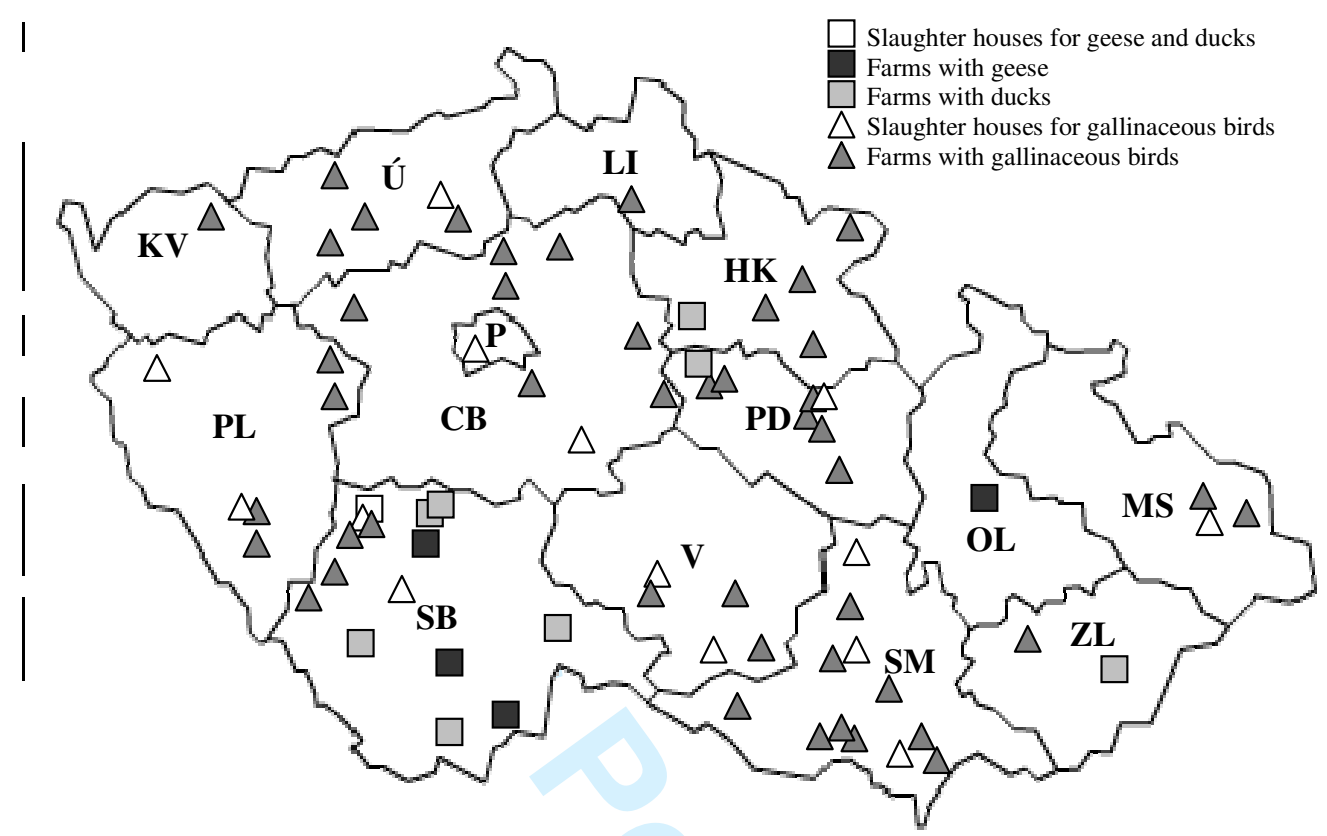

Districts: SB - South Bohemian; PL - Plzeň; KV - Karlovy Vary; Ú - Ústí nad Labem; LI - Liberec; CB Central Bohemian; P - Prague; HK - Hradec Králové; PD - Pardubice; V - Vysočina; SM - South Moravian; OL - Olomouc; MS - Moravian-Silesian; ZL - Zlín. 